\title{
Micropropagation of Ficus religiosa L. via leaf explants and comparative evaluation of acetylcholinesterase inhibitory activity in the micropropagated and conventionally grown plants
}

\author{
Priyanka Siwach $\cdot$ Anita Rani Gill
}

Received: 24 June 2013/Accepted: 19 September 2013/Published online: 4 October 2013

(C) The Author(s) 2013. This article is published with open access at Springerlink.com

\begin{abstract}
A high-frequency, season-independent, in vitro regeneration of Ficus religiosa was developed, followed by comparative acetylcholinesterase inhibitory (AChEI) activity assay of the in vitro raised and conventionally grown plants. The use of AChEI activity is the most accepted strategy for the treatment of Alzheimer disease. Fully expanded, mature leaves were cut into different segments to initiate the cultures. The middle section of the leaf in vertical orientation with cut portion inserted inside the medium was found most suitable for direct shoot regeneration. Leaf explants responded with nearly consistent frequency $(60-66.67 \%)$ throughout the year. To obtain high frequency response with enhanced shoot multiplication rate, 32 plant growth regulator regimes were screened amongst which benzylaminopurine at $5.0 \mathrm{mg} / \mathrm{l}$ was found most suitable, yielding $100 \%$ response and maximum number of shoots per explant (7.93); same concentration was also most supportive for repeated multiplication (6.53 shoots). The quality of the shoots and multiplication rate could be significantly enhanced ( 24.35 shoots) when adenine sulphate, glutamine and phloroglucinol, in an optimised concentration, were additionally supplemented. The clonal nature of the micropropagated plants was confirmed by random amplified polymorphic DNA analysis. A comparative analysis of AChEI activity was carried out amongst the methanolic extracts of stem segments of the mother plant, randomly selected seedlings of different age (4 and 6 months old) of the same mother plant and randomly selected micropropagated plants of different age ( 3 and 6 months age). The mother plant
\end{abstract}

P. Siwach $(\varangle)$. A. R. Gill

Department of Biotechnology, Chaudhary Devi Lal University,

Sirsa, Haryana, India

e-mail: psiwach29@gmail.com sample showed effective AChEI activity, with $\mathrm{IC}_{50}$ of $66.46 \mu \mathrm{g} / \mathrm{ml}$ while seedlings, of different age groups, performed poorly (6-month-old seedlings, Se- $1_{6 \mathrm{M}}$, yielded $\mathrm{IC}_{50}$ of $20,538.46 \mu \mathrm{g} / \mathrm{ml}$, while two randomly selected 4 months' aged seedlings, Se- $2_{4 \mathrm{M}}$ and Se- $3_{4 \mathrm{M}}$ exhibited $\mathrm{IC}_{50}$ of $19,341.03$ and $24,281.70 \mu \mathrm{g} / \mathrm{ml}$ ). On the other hand, various micropropagated plants, 2 of 3 months (MiP$\left.1_{3 \mathrm{M}}, \mathrm{MiP}-2_{3 \mathrm{M}}\right)$ and 2 of 6 months $\left(\mathrm{MiP}-3_{6 \mathrm{M}}\right.$ and $\left.\mathrm{MiP}-4_{6 \mathrm{M}}\right)$ age behaved like the mother plant, exhibiting $\mathrm{IC}_{50}$ values of $71.87,72.91,67.65$ and $69.65 \mu \mathrm{g} / \mathrm{ml}$, respectively.

Keywords In vitro regeneration - Shoot multiplication . Clonal nature $\cdot$ RAPD markers $\cdot$ Acetylcholinesterase inhibitory activity $\cdot$ Alzheimer disease

$\begin{array}{ll}\text { Abbreviations } \\ \text { BAP } & \text { Benzylaminopurine } \\ \text { IAA } & \text { Indole acetic acid } \\ \text { TDZ } & \text { Thidiazuron } \\ \text { ADS } & \text { Adenine sulphate } \\ \text { PGR } & \text { Plant growth regulator } \\ \text { AChE } & \text { Acetylcholinesterase } \\ \text { AD } & \text { Alzheimer disease } \\ \text { MiP } & \text { Micropropagated plant } \\ \text { MP } & \text { Mother plant } \\ \text { Se } & \text { Seedling } \\ \text { RAPD } & \text { Randomly amplified polymorphic DNA }\end{array}$

\section{Introduction}

Ficus religiosa, the Sacred Fig or Bo-Tree, belonging to family Moraceae, is a large heavily branched tree with 
long petiolated, heart-shaped leaves. The tree is native to India and Nepal where it has great ethano-medicinal and religious importance since times immemorial. Different parts of the tree render applications for more than 50 disorders, which are well documented in Ayurveda, the indigenous Indian medicine system (Singh et al. 2011). Many of these have been confirmed by various pharmacological studies (Kirana et al. 2009; Pandit et al. 2010). One of the most affective and popular use of $F$. religiosa is in the treatment of cognitive decline, improving memory and related central nervous system disorders (Singh and Goel 2009). A number of traditional practitioners in north India prepare specific herbal formulations from stem bark of $F$. religiosa for treatment of memory loss and various neuro-degenerative disorders (Personal communication). The scientific basis for this was revealed by Vinutha et al. (2007), who while analysing the methanolic stem bark extract of $F$. religiosa, found potent acetylcholinesterase inhibitory (AChEI) activity associated with it. The latter is the most accepted strategy for the treatment of Alzheimer disease (AD) and other related diseases (Bertaccini 1982); the inhibitors prolong the halflife of acetylcholine through inhibition of acetylcholinesterase (AChE) (Darvesh et al. 2003). Since, the present day drugs for $\mathrm{AD}$ (tacrine, donepezil, rivastigime and galanthamine) are suffering with short-half-lives and/or unfavourable side effects such as hepatotoxicity, low bioavailability, adverse cholinergic side effects and a narrow therapeutic window (Sancheti et al. 2009), F. religiosa is being looked upon as a potential source of a new drug for AD. The phytochemical analysis of bark and stem of $F$. religiosa has led to the isolation of phytosterols, amino acids, furanocoumarins, phenolic components, flavonoids, saponins and acid detergent fibres (Ambike and Rao 1967; Swami et al. 1989; Swami and Bisht 1996); however, those responsible for AChEI activity are yet to be identified. There is a need to characterise and exploit the AChEI activity found in the stem bark of $F$. religiosa at the commercial level. Conventionally, the tree is propagated by seeds, which remain viable for a few months and the plants produced are not true to types. The vegetative propagation by cutting is not efficient under varied climatic conditions. The nature and amount of secondary metabolites in different parts of the plants is greatly affected by the environmental condition and so naturally propagated plants are unable to yield consistent yield of secondary metabolites throughout the year (Gurel et al. 2011; Tamara et al. 2011). Micropropagation is a proven method for large-scale production of true-to-type medicinal plants capable of yielding desired plant-derived pharmaceuticals with consistent quality and amount (Pattnaik and Chand 1996; Jiang et al. 2012).
In vitro propagation methods also offer the opportunity to correlate the secondary metabolite production with several parameters like nutritional and hormonal composition of nutrient medium, growth conditions, duration of culture, etc., and so are better for production of plants for commercial, pharmaceutical applications (Gurel et al. 2011).

Some previous work on in vitro propagation of $F$. religiosa $\mathrm{L}$. using nodal segments as explants has been carried out by Jaiswal and Narayan (1985), Deshpande et al. (1998), and Hassan et al. (2009). In an attempt to further improve the micropropagation protocol (Siwach and Gill 2011), it was observed that response of nodal segments as well as frequency of contamination under in vitro conditions was strongly influenced by the season of explants collection, restricting the culture initiation experiment to a particular time-period of the year (Siwach et al. 2011). Similar observations were also observed with apical shoot explants (data not shown). The seasonal influence on the establishment and response of in vitro cultures of perennial trees is due to their periodic development and is one of the major hurdles towards commercialisation of micropropagation for these plants as it cannot be overcome by environmental or nutritional manipulations (Siril and Dhar 1997; McCown 2000).

Therefore, a need was felt to formulate a commercially viable micropropagation protocol for $F$. religiosa $\mathrm{L}$., which would be beyond the seasonal constraints. Axillary and apical meristematic cells (on the nodal and apical explants respectively), of the perennial trees, are genetically directed to divide actively during the active growth season, and this periodic growth direction may not be there with the differentiated tissues like leaves. There exists one study reporting the use of leaves as explants for in vitro propagation of F. religiosa (Narayan and Jaiswal 1986). However, the study pertains to indirect shoot organogenesis from leaves through the callus phase and does not discuss about the seasonal influence on the in vitro response of leaves' explants. So during the present study, experiments were initiated with fully expanded mature leaf segments to optimise season independent protocol for $F$. religiosa. It was planned to go specifically for direct shoot regeneration followed by confirming the clonal nature of plants by randomly amplified polymorphic DNA (RAPD) based molecular analysis. The latter has been reported as a reliable method for monitoring the genetic stability of micropropagated plants in many species (Khan and Spoor 2001). To explore the pharmaceutical potential of micropropagated plants, present study was extended to carry out comparative AChE inhibitory activity assay among the stem tissue of randomly selected micropropagated plants, randomly selected seedlings of the same mother plant and mother plant itself. 
Table 1 Effect of different orientations of various cut leaf sections of Ficus religiosa L. on shoot organogenesis (cultured on MS medium having $1.0 \mathrm{mg} / \mathrm{l} \mathrm{BAP}$ )

\begin{tabular}{|c|c|c|c|c|c|}
\hline Cut leaf section & Orientation & Response (\%) & $\begin{array}{l}\text { No. of shoot } \\
\text { buds }\end{array}$ & $\begin{array}{l}\text { No. of } \\
\text { shoots }\end{array}$ & $\begin{array}{l}\text { Length of } \\
\text { shoots }^{B}\end{array}$ \\
\hline \multirow[t]{3}{*}{$\begin{array}{l}\text { Proximal section with } \\
\text { petiole }\end{array}$} & $\begin{array}{l}\text { Cut portion inserted vertically in } \\
\text { medium }\end{array}$ & $40.00^{\mathrm{abc}} \pm 9.09$ & $3.33^{\mathrm{b}} \pm 0.15$ & $3.40^{\mathrm{b}} \pm 0.18$ & $1.97^{\mathrm{bc}} \pm 0.18$ \\
\hline & Adaxial side touching the medium & $36.67^{\mathrm{abc}} \pm 8.95$ & $2.80^{\mathrm{c}} \pm 0.11$ & $2.53^{\mathrm{c}} \pm 0.11$ & $2.13^{\mathrm{bc}} \pm 0.19$ \\
\hline & Abaxial side touching the medium & $33.33^{\mathrm{bc}} \pm 8.75$ & $1.33^{\mathrm{e}} \pm 0.11$ & $1.47^{\mathrm{d}} \pm 0.13$ & $1.67^{\mathrm{c}} \pm 0.09$ \\
\hline \multirow[t]{3}{*}{ Middle section } & $\begin{array}{l}\text { Cut portion inserted vertically in } \\
\text { medium }\end{array}$ & $63.33^{\mathrm{a}} \pm 8.95$ & $4.83^{\mathrm{a}} \pm 0.18$ & $4.57^{\mathrm{a}} \pm 0.13$ & $2.67^{\mathrm{a}} \pm 0.19$ \\
\hline & Adaxial side touching the medium & $60.00^{\mathrm{ab}} \pm 9.09$ & $3.47^{\mathrm{b}} \pm 0.21$ & $3.37^{b} \pm 0.19$ & $2.13^{\mathrm{bc}} \pm 0.12$ \\
\hline & Abaxial side touching the medium & $56.67^{\mathrm{abc}} \pm 9.20$ & $3.23^{\mathrm{bc}} \pm 0.20$ & $2.33^{\mathrm{c}} \pm 0.11$ & $2.03^{\mathrm{bc}} \pm 00.11$ \\
\hline \multirow[t]{3}{*}{ Distal section with leaf tip } & $\begin{array}{l}\text { Cut portion inserted vertically in } \\
\text { medium }\end{array}$ & $36.67^{\mathrm{abc}} \pm 8.95$ & $2.23^{\mathrm{d}} \pm 0.18$ & $2.17^{\mathrm{c}} \pm 0.14$ & $2.47^{\mathrm{ab}} \pm 0.17$ \\
\hline & Adaxial side touching the medium & $33.33^{\mathrm{bc}} \pm 8.75$ & $1.53^{\mathrm{e}} \pm 0.21$ & $1.17^{\mathrm{d}} \pm 0.14$ & $2.17^{\mathrm{bc}} \pm 0.18$ \\
\hline & Abaxial side touching the medium & $30.00^{\mathrm{c}} \pm 8.50$ & $1.33^{\mathrm{e}} \pm 0.09$ & $1.17^{\mathrm{d}} \pm 0.08$ & $2.13^{\mathrm{bc}} \pm 0.17$ \\
\hline
\end{tabular}

Data are means from 10 replicates $\pm \mathrm{SE}$ and those representing similar letter in the appropriate column are not significantly different (ANOVA, $P \leq 0.05$ ), (groupings applying to whole table)

A Observed after 4 weeks of culture

B Observed after 60 days of initial culture

\section{Materials and methods}

Plant materials

Fully grown, healthy looking leaves were excised from third to sixth node from the tip of a healthy branch of a 45-50-year-old tree of $F$. religiosa L., selected as the mother plant (MP) for the present study, growing near the campus area of Chaudhary Devi Lal University, Sirsa, Haryana, India. The leaves were kept for 15 min under running tap water to remove the traces of dust and were surface sterilised as described earlier (Siwach and Gill 2011). The surface sterilised leaves were used as explants for direct shoot regeneration in the present study.

Seeds of the same mother plant were also sown in the month of March (seeds are available during months of March to June in North India) under greenhouse conditions and were properly taken care of. Among various seedlings so obtained, three seedlings of different ages were randomly selected. One seedling was of 6 months age (named as $\mathrm{Se}-1_{6 \mathrm{~m}}$ ) while other two were of 4 months age (named as Se- $2_{4 \mathrm{M}}$ and Se- $3_{4 \mathrm{M}}$ ). These three seedlings were used for comparison with micropropagated plants in different analysis, reported below.

\section{Effect of explant orientation on shoot organogenesis}

The surface sterilised leaves, as obtained above, were cut into three sections-proximal section with petiole, middle section and distal section with leaf tip. Each section was further cultured in three orientations-cut portion inserted in medium, adaxial surface touching the medium and abaxial surface touching the medium. Murashige and Skoog's medium (1962), (MS) supplemented with $1.0 \mathrm{mg} / \mathrm{l}$ benzylaminopurine (BAP) was used for this experiment. The number of explants initiating shoot buds (percentage of response) and the average number of shoot buds per explant was recorded after 28 days of culture. The explants with sprouted shoot buds/shoots were shifted to the same medium as such within an interval of 30 days so as to score the number of shoots and the length of shoots after 60 days of initial culture (Table 1). Every treatment contained ten replicates and the experiment was repeated thrice. These experiments were carried out during January-February, 2009.

Using the most suitable orientation of the leaf segments as obtained from above experiment, following two studies were carried out in parallel.

\section{Effect of season of explant collection on percentage of response of explants}

The cut leaf segments, in the most suitable orientation as deduced from above experiment, were cultured every month from March 2009-February 2010. The MS basal medium supplemented with $1.0 \mathrm{mg} / \mathrm{l} \mathrm{BAP}$ was employed for this study. There were 20 replicates for each month and the observations were recorded after 4 weeks of culture. 
Table 2 Effect of various concentrations and combinations of BAP, TDZ and IAA on shoot organogenesis from leaf explants

\begin{tabular}{|c|c|c|c|c|c|c|}
\hline \multicolumn{3}{|c|}{ PGR (mg/l) } & \multirow[t]{2}{*}{ Response (\%) } & \multirow[t]{2}{*}{ No. of shoot buds } & \multirow[t]{2}{*}{ No. of shoots ${ }^{B}$} & \multirow[t]{2}{*}{ Length of shoots $(\mathrm{cm})$} \\
\hline BAP & TDZ & IAA & & & & \\
\hline 1.0 & - & - & $63.33^{\text {bcdefg }} \pm 8.95$ & $4.80^{\mathrm{fg}} \pm 0.23$ & $4.53^{\mathrm{d}} \pm 0.16$ & $2.67^{\text {abcde }} \pm 0.16$ \\
\hline 1.5 & - & - & $60.0^{\text {cdefgh }} \pm 9.09$ & $3.93^{\text {hijk }} \pm 0.33$ & $4.57^{\mathrm{d}} \pm 0.18$ & $2.47^{\text {defg }} \pm 0.09$ \\
\hline 2.0 & - & - & $66.67^{\text {bcdef }} \pm 8.75$ & $3.93^{\text {hijk }} \pm 0.28$ & $4.33^{\mathrm{de}} \pm 0.24$ & $2.23^{\text {efgh }} \pm 0.12$ \\
\hline 2.5 & - & - & $66.67^{\text {bcdef }} \pm 8.75$ & $3.20^{\mathrm{kl}} \pm 0.25$ & $4.07^{\mathrm{de}} \pm 0.29$ & $2.07^{\mathrm{ghi}} \pm 0.14$ \\
\hline 3.0 & - & - & $73.3^{\text {bcde }} \pm 8.21$ & $3.73^{\mathrm{ijkl}} \pm 0.35$ & $2.53^{\mathrm{jk}} \pm 0.22$ & $2.50^{\text {cdefg }} \pm 0.14$ \\
\hline 3.5 & - & - & $76.67^{\mathrm{abcd}} \pm 7.85$ & $3.93^{\text {hijk }} \pm 0.41$ & $3.13^{\mathrm{hi}} \pm 0.21$ & $2.53^{\text {bcdef }} \pm 0.11$ \\
\hline 4.0 & - & - & $80.0^{\mathrm{abc}} \pm 7.42$ & $4.23^{\mathrm{ghi}} \pm 0.31$ & $4.20^{\mathrm{de}} \pm 0.29$ & $2.33^{\text {defgh }} \pm 0.18$ \\
\hline 4.5 & - & - & $83.33^{\mathrm{abc}} \pm 6.92$ & $4.17^{\text {ghij }} \pm 0.19$ & $4.47^{\mathrm{d}} \pm 0.19$ & $2.93^{\mathrm{abc}} \pm 0.15$ \\
\hline 5.0 & - & - & $100.0^{\mathrm{a}} \pm 0$ & $5.83^{\mathrm{e}} \pm 0.19$ & $7.93^{\mathrm{a}} \pm 0.20$ & $2.97^{\mathrm{ab}} \pm 0.13$ \\
\hline 5.5 & - & - & $90.0^{\mathrm{ab}} \pm 5.57$ & $4.13^{\text {ghij }} \pm 0.31$ & $3.23^{\mathrm{ghi}} \pm 0.08$ & $2.20^{\mathrm{fgh}} \pm 0.10$ \\
\hline 6.0 & - & - & $63.33^{\text {bcdefg }} \pm 8.95$ & $2.13^{\mathrm{n}} \pm 0.08$ & $1.17^{\mathrm{m}} \pm 0.07$ & $2.17^{\mathrm{fgh}} \pm 0.09$ \\
\hline 1.0 & - & 0.5 & $43.33^{\text {fghij }} \pm 9.20$ & $3.70^{\mathrm{ijkl}} \pm 0.22$ & $7.27^{b} \pm 0.23$ & $2.77^{\mathrm{abcd}} \pm 0.17$ \\
\hline 1.5 & - & 0.5 & $40.0^{\text {fghij }} \pm 9.09$ & $3.23^{\mathrm{kl}} \pm 0.10$ & $3.47^{\mathrm{fgh}} \pm 0.19$ & $3.07^{\mathrm{a}} \pm 0.15$ \\
\hline 2.0 & - & 0.5 & $36.67^{\text {ghij }} \pm 8.95$ & $3.43^{\mathrm{ijkl}} \pm 0.12$ & $3.97^{\mathrm{def}} \pm 0.21$ & $2.43^{\operatorname{defg}} \pm 0.11$ \\
\hline 2.5 & - & 0.5 & $36.67^{\text {ghij }} \pm 8.95$ & $3.07^{1 \mathrm{~m}} \pm 0.18$ & $3.33^{\mathrm{ghi}} \pm 0.22$ & $1.67^{\text {hijk }} \pm 0.15$ \\
\hline 3.0 & - & 0.5 & $40.0^{\text {fghij }} \pm 9.09$ & $3.33^{\mathrm{jkl}} \pm 0.23$ & $3.77^{\mathrm{efg}} \pm 0.21$ & $1.57^{\mathrm{ijk}} \pm 0.18$ \\
\hline 3.5 & - & 0.5 & $36.67^{\text {ghij }} \pm 8.95$ & $3.33^{\mathrm{jkl}} \pm 0.22$ & $2.77^{\mathrm{ij}} \pm 0.27$ & $1.43^{\mathrm{jkl}} \pm 0.16$ \\
\hline 4.0 & - & 0.5 & $33.33^{\text {hij }} \pm 8.75$ & $3.93^{\text {hijk }} \pm 0.12$ & $2.10^{\mathrm{k}} \pm 0.19$ & $2.57^{\text {bcdef }} \pm 0.18$ \\
\hline 4.5 & - & 0.5 & $46.67^{\text {efghij }} \pm 9.26$ & $3.78^{\mathrm{ijkl}} \pm 0.20$ & $4.30^{\mathrm{de}} \pm 0.26$ & $2.97^{\mathrm{ab}} \pm 0.20$ \\
\hline 5.0 & - & 0.5 & $63.33^{\text {bcdefg }} \pm 8.95$ & $4.67^{\mathrm{gh}} \pm 0.15$ & $5.53^{\mathrm{c}} \pm 0.32$ & $2.67^{\text {abcde }} \pm 0.27$ \\
\hline 5.5 & - & 0.5 & $50.0^{\text {defghi }} \pm 9.28$ & $2.23^{\mathrm{n}} \pm 0.09$ & $3.13^{\mathrm{hi}} \pm 0.18$ & $2.13^{\mathrm{fgh}} \pm 0.13$ \\
\hline 6.0 & - & 0.5 & $36.67^{\text {ghij }} \pm 8.95$ & $2.13^{\mathrm{n}} \pm 0.08$ & $1.07^{\mathrm{m}} \pm 0.08$ & $1.97^{\text {hij }} \pm 0.20$ \\
\hline- & 1.0 & - & $63.33^{\text {bcdefg }} \pm 8.95$ & $5.50^{\mathrm{ef}} \pm 0.16$ & $2.77^{\mathrm{ij}} \pm 0.23$ & $1.07^{\mathrm{kl}} \pm 0.05$ \\
\hline- & 1.5 & - & $60.0^{\text {cdefgh }} \pm 9.09$ & $4.83^{\mathrm{fg}} \pm 0.25$ & $2.33^{\mathrm{jk}} \pm 0.22$ & $1.37^{\mathrm{jkl}} \pm 0.16$ \\
\hline- & 2.0 & - & $43.33^{\text {fghij }} \pm 9.20$ & $2.43^{\mathrm{mn}} \pm 0.41^{\mathrm{A}}$ & $2.10^{\mathrm{k}} \pm 0.13$ & $1.33^{\mathrm{jkl}} \pm 0.14$ \\
\hline- & 2.5 & - & $33.33^{\text {hij }} \pm 8.75$ & $2.33^{\mathrm{mn}} \pm 0.22^{\mathrm{A}}$ & $2.03^{\mathrm{kl}} \pm 0.19$ & $1.57^{\mathrm{ijk}} \pm 0.14$ \\
\hline- & 3.0 & - & $30.33^{\mathrm{ij}} \pm 8.51$ & $1.97^{\mathrm{n}} \pm 0.22^{\mathrm{A}}$ & $1.83^{1} \pm 0.19$ & $1.47^{\mathrm{jkl}} \pm 0.14$ \\
\hline- & 1.0 & 0.5 & $26.67^{\mathrm{ij}} \pm 8.21$ & $10.17^{\mathrm{b}} \pm 0.39^{\mathrm{A}}$ & 0 & - \\
\hline- & 1.5 & 0.5 & $33.33^{\text {hij }} \pm 8.75$ & $12.33^{\mathrm{a}} \pm 0.36^{\mathrm{A}}$ & 0 & - \\
\hline- & 2.0 & 0.5 & $30.0^{\mathrm{ij}} \pm 8.51$ & $9.30^{\mathrm{c}} \pm 0.36^{\mathrm{A}}$ & 0 & - \\
\hline- & 2.5 & 0.5 & $23.33^{\mathrm{ij}} \pm 7.85$ & $8.87^{\mathrm{c}} \pm 0.27^{\mathrm{A}}$ & 0 & - \\
\hline- & 3.0 & 0.5 & $20.0^{\mathrm{ij}} \pm 7.43$ & $7.07^{\mathrm{d}} \pm 0.17^{\mathrm{A}}$ & 0 & - \\
\hline
\end{tabular}

Data are means from 30 replicates $\pm \mathrm{SE}$ and those representing similar letter in the appropriate column are not significantly different (ANOVA, $P \leq 0.05)$, (groupings applying to whole table)

${ }^{\text {A }}$ Extensive callus formation, ${ }^{\mathrm{B}}$ observed after 60 days of culture

\section{Effect of plant growth regulators on direct shoot regeneration}

It was carried out during the period of March-July, 2009. The cut leaf sections in most suitable orientation as obtained above were inoculated on MS medium supplemented with various concentrations and combinations of BAP, thidiazuron (TDZ) and indole acetic acid (IAA). The observations were made for shoot organogenesis as reported above (Table 2). For each of these treatments, 20 explants were used and the experiment was repeated thrice.
Shoot multiplication during sub-culturing

The shoots regenerated from leaf explant were excised from the explant surface and were cultured in cluster of 2-3 shoots on six different medium. MS medium having most suitable PGR regime deduced from above study was taken as control. Two more concentrations of the selected PGR, lower than that in control, were also screened. These three media were further modified with specific combination of three additives_-glutamine $(200 \mathrm{mg} / \mathrm{l})$, adenine sulphate (ADS) $(150 \mathrm{mg} / \mathrm{l})$ and phloroglucinol $(100 \mathrm{mg} / \mathrm{l})$, which 
Table 3 Effect of different concentrations of BAP, with or without optimised additives, on shoot multiplication as well as quality of shoots (observations recorded after 5 weeks of culture)

\begin{tabular}{|c|c|c|c|c|}
\hline BAP (mg/l) & Medium additives & No. of shoots & Length of shoots $(\mathrm{cm})$ & Comments $^{\mathrm{A}}$ \\
\hline 5.0 (control) & No additive & $6.53^{\mathrm{d}} \pm 0.14$ & $2.97^{\mathrm{ab}} \pm 0.13$ & -- \\
\hline 2.5 & No additive & $4.07^{\mathrm{e}} \pm 0.29$ & $2.07^{\mathrm{c}} \pm 0.14$ & -- \\
\hline 1.0 & No additive & $4.53^{\mathrm{e}} \pm 0.16$ & $2.67^{\mathrm{b}} \pm 0.16$ & -- \\
\hline 5.0 & With optimised additives ${ }^{B}$ & $24.37^{\mathrm{a}} \pm 0.34$ & $3.17^{\mathrm{a}} \pm 0.15$ & +++ \\
\hline 2.5 & With optimised additives ${ }^{B}$ & $17.17^{\mathrm{b}} \pm 0.09$ & $2.23^{\mathrm{c}} \pm 0.13$ & +++ \\
\hline 1.0 & With optimised additives ${ }^{\mathrm{B}}$ & $15.03^{\mathrm{c}} \pm 0.21$ & $2.17^{\mathrm{c}} \pm 0.08$ & +++ \\
\hline
\end{tabular}

Data are means from 30 replicates $\pm \mathrm{SE}$ and those representing similar letter in the appropriate columns are not significantly different (ANOVA, $P \leq 0.05)$ (groupings applying to whole table)

A -- (Chlorosis, leaf fall), +++ (no chlorosis, no leaf fall, increased vigour of shoots)

B $200 \mathrm{mg} / \mathrm{l}$ glutamine $+150 \mathrm{mg} / \mathrm{l}$ adenine sulphate $+100 \mathrm{mg} / \mathrm{l}$ phloroglucinol

was earlier reported to support the shoot proliferation during repeated sub-culturing (Siwach and Gill 2011). Observations were recorded after 35 days of culture (Table 3). For each of the above treatment, 20 replicates were used and the experiment was repeated thrice.

In vitro rooting, acclimatisation and transplantation

Individual shoots were subjected to in vitro rooting, acclimatisation and transplantation as reported previously (Siwach and Gill 2011).

Culture conditions

MS medium, modified with different growth regulators as per requirement as reported above, was supplemented with $3 \%(\mathrm{w} / \mathrm{v})$ sucrose and solidified with $0.8 \%(\mathrm{w} / \mathrm{v})$ agar. The $\mathrm{pH}$ of medium was adjusted to 5.8 using $0.1 \mathrm{~N} \mathrm{NaOH}$ or $0.1 \mathrm{~N} \mathrm{HCl}$, before autoclaving at $15 \mathrm{~kg} / \mathrm{cm}^{2}$ and $121{ }^{\circ} \mathrm{C}$ for $20 \mathrm{~min}$. The cultures were maintained at $25 \pm 2{ }^{\circ} \mathrm{C}$, at a photoperiod of $16 \mathrm{~h}\left(80 \mu \mathrm{mol} \mathrm{m}{ }^{-2} \mathrm{~s}^{-1}\right)$ in a culture room.

Checking the clonal fidelity of micropropagated plants

Six micropropagated plants, of different age $(1,2,4,5,6$ and 7 months aged, after transplantation) were randomly selected for this. Three seedlings-Se- $1_{6 \mathrm{M}}, \mathrm{Se}-2_{4 \mathrm{M}}$ and $\mathrm{Se}-3_{4 \mathrm{M}}$, discussed above in the "Plant material" sub-section, were also selected to check their clonal fidelity. Mother plant sample was taken as reference sample. Young leaves were excised from the above listed ten samples and were subjected to DNA isolation using Cetyl trimethyl ammonium bromide (CTAB) method (Sanghai-Maroof et al. 1984). Qualitative and quantitative assessment of total genomic DNA was carried out by spectrophotometer as well as agarose gel electrophoresis, followed by DNA purification.
Twenty RAPD primers, procured from Bangalore Genie Pvt. Ltd., were used for amplification (Table 4). Polymerase Chain Reaction (PCR) was carried out in a total volume of $15 \mu \mathrm{l}$ with each reaction tube comprising of $8.1 \mu \mathrm{l}$ of PCR water, $1.5 \mu$ of PCR buffer containing $\mathrm{MgCl}_{2}(10 \mathrm{X})$, $2.4 \mu \mathrm{l}$ of dNTPs mixture $(5 \mathrm{mM}), 1.2 \mu \mathrm{l}$ of primers $(10 \mu \mathrm{M}), 1.5 \mu \mathrm{l}(10 \mathrm{ng} / \mu \mathrm{l})$ of template DNA, and $0.3 \mu \mathrm{l}$ of Taq DNA polymerase. Amplification was carried out using Bio-Rad thermal-cycler and was run for 35 cycles; each cycle consisting of a denaturation step at $94{ }^{\circ} \mathrm{C}(1 \mathrm{~min})$, a primer annealing step at $36{ }^{\circ} \mathrm{C}(1 \mathrm{~min})$ followed by amplification at $72{ }^{\circ} \mathrm{C}(3 \mathrm{~min})$. Amplified products were loaded on $1.5 \%$ agarose gel along with 100 bp ladder (GE Healthcare Life Sciences) and electrophoresis was carried out at $100 \mathrm{~V}$. Gel was stained with $25 \mu \mathrm{g} / \mathrm{ml}$ ethidium bromide and photographed on a Gel Documentation Polaroid system (Bio-Rad).

Sample preparation for AChE inhibitory activity assay

Mother plant sample (MP) was taken as reference for this. Four micropropagated plants of different age (two plants after 3 months of transplantation-MiP- $1_{3 \mathrm{M}}$ and $\mathrm{MiP}-2_{3 \mathrm{M}}$, and two plants after 6 months of transplantation-MiP- $3_{6 \mathrm{M}}$ and MiP- $4_{6 \mathrm{M}}$ ) were randomly selected. Three seedlingsSe- $1_{6 \mathrm{M}}, \mathrm{Se}-2_{4 \mathrm{M}}$ and $\mathrm{Se}-3_{4 \mathrm{M}}$ were also taken for AChEI activity assay. The MP selected was of 45-50 years old, the age when higher secondary metabolites are reported to be present in stem bark. On the other hand, the other plants selected were of 3-6 months age as reported above. So to avoid the huge difference in the development stage of these plants, young, fresh, thin branches of mother plant was taken as sample (Fig. 1a) instead of stem bark or older branches. Likewise for seedlings and micropropagated plants also, young branches were excised (Fig. 1b). After excision, young branches were defoliated and cut into small-sized pieces followed by thorough washing with 
Table 4 Amplification profile obtained with selected 20 RAPD primers, during the present study

\begin{tabular}{|c|c|c|c|c|c|c|}
\hline \multirow{2}{*}{$\begin{array}{l}\text { Sr } \\
\text { no. }\end{array}$} & \multirow[t]{2}{*}{ Primer sequence } & \multicolumn{5}{|c|}{ Band size of amplified products (bp) } \\
\hline & & Mother plant & $\begin{array}{l}\text { Micropropagated } \\
\text { plants }\end{array}$ & $\mathrm{Se}-1_{6 \mathrm{M}}$ & $\mathrm{Se}-2_{4 \mathrm{M}}$ & $\mathrm{Se}-3_{4 \mathrm{M}}$ \\
\hline 1 & CAGGCCCTTC & 500 & 500 & $500,670^{\mathrm{A}}$ & 500 & $500,600^{\mathrm{A}}$ \\
\hline 2 & TGCCGAGCTG & $1,200,700$ & $1,200,700$ & $700,840^{\mathrm{A}}$ & 700 & 700 \\
\hline 3 & AGTCAGCCAC & 500 & 500 & 500 & 500 & 500 \\
\hline 4 & AATCGGGCTG & $200,300,400,500$ & $200,300,400,500$ & $200,300,400,500$ & $200,300,400,500$ & $200,300,400,500$ \\
\hline 5 & AGGGGTCTTG & NA & NA & NA & NA & NA \\
\hline 6 & GGTCCCTGAC & NA & NA & NA & NA & NA \\
\hline 7 & GAAACGGGTG & NA & NA & NA & NA & NA \\
\hline 8 & GTGACGTAGG & NRA & NRA & NRA & NRA & NRA \\
\hline 9 & GGGTTTCGCC & $240,340,440$ & $240,340,440$ & $300^{\mathrm{A}}, 590^{\mathrm{A}}, 610^{\mathrm{A}}$ & $\begin{array}{l}240,340,440,590^{\mathrm{A}}, \\
610^{\mathrm{A}}\end{array}$ & $\begin{array}{l}240,340,440,590^{\mathrm{A}} \\
610^{\mathrm{A}}\end{array}$ \\
\hline 10 & GTGATCGCAG & NRA & NRA & NRA & NRA & NRA \\
\hline 11 & TAATCGGCGT & $\begin{array}{l}260,350,410 \\
600,700\end{array}$ & $\begin{array}{l}260,350,410 \\
600,700\end{array}$ & $\begin{array}{l}150^{\mathrm{A}}, 260,350,410,600, \\
700,900^{\mathrm{A}}\end{array}$ & $350,410,600,700$ & $\begin{array}{l}150^{\mathrm{A}}, 260,350,410, \\
600,700\end{array}$ \\
\hline 12 & TCGGCGATAG & $280,370,480$ & $280,370,480$ & $280,370,480$ & $280,370,480$ & $280,370,480$ \\
\hline 13 & CAGCACCCAC & $\begin{array}{l}280,340,500, \\
520,600\end{array}$ & $\begin{array}{l}280,340,500, \\
520,600\end{array}$ & $280,340,500,520,600$ & $\begin{array}{l}280,340,500,520 \\
\quad 600\end{array}$ & $280,340,500,520,600$ \\
\hline 14 & TCTGTGCTGG & $\begin{array}{c}170,380,480 \\
690,790\end{array}$ & $\begin{array}{c}170,380,480 \\
690,790\end{array}$ & $170,380,480,690,790$ & $\begin{array}{l}170,380,480,690 \\
790\end{array}$ & $170,380,480,690,790$ \\
\hline 15 & TTCCAAACCC & NA & NA & NA & NA & NA \\
\hline 16 & TGCCATCGAA & NA & NA & NA & NA & NA \\
\hline 17 & GGCGGCTTGT & 300,400 & 300,400 & 300,400 & 300,400 & 300,400 \\
\hline 18 & ATTGACCGT & 550 & 550 & 550 & 550 & 550 \\
\hline 19 & CAAACGTCGG & $300,550,700$ & $300,550,700$ & $300,550,700$ & $300,550,700$ & $300,550,700$ \\
\hline 20 & GTTGCGATCC & $420,580,640$ & $420,580,640$ & $420,580,640$ & $420,580,640$ & $420,580,640$ \\
\hline
\end{tabular}

$N A$ No amplification, $N-R A$ non-reproducible band pattern

A Polymorphic bands

sterilised double distilled water. These were then dried in an oven at $32{ }^{\circ} \mathrm{C}$. The dried pieces were finely ground to a fine powder using mixer grinder. The $15 \mathrm{~g}$ of dried fine powder of each sample was macerated separately with HPLC (high performance liquid chromatography) grade methanol $(75 \mathrm{ml})$ at room temperature for $24 \mathrm{~h}$. The extracts were obtained by filtration using Whatman No. 1 filter paper and concentrated to dryness. Working concentrations of methanolic extracts of each of the eight samples were prepared by completely dissolving the dried extract in methanol in ratio $1: 1$ to have stock solution of strength $1 \mathrm{mg} / \mathrm{ml}$.

AChE inhibitory activity assay

For each of the eight samples, five dilutions of 20, 40, 60, 80 and $100 \mu \mathrm{g} / \mathrm{ml}$ concentration were prepared. The assay for measuring AChEI activity was modified from the method described by Ellman et al. (1961) and Ingkaninan et al.
(2000). Briefly, $4 \mu \mathrm{l}$ of $3 \mathrm{mM}$ dithiobis nitrobenzoic acid (DTNB), $20 \mu \mathrm{l}$ of $15 \mathrm{mM}$ acetylthiocholine iodide (ATCI), $130 \mu \mathrm{l}$ Tris- $\mathrm{HCl}$ and $20 \mu \mathrm{l}$ of each diluted sample was taken and added to the wells of microplate, followed by $50 \mu \mathrm{l}$ of $0.28 \mathrm{U} / \mathrm{ml}$ AChE enzyme. The microplate was then read at $405 \mathrm{~nm}$ every $5 \mathrm{~s}$ for $2 \mathrm{~min}$ by a CERES micoplate reader (Spectra Max Plus 384, Molecular Devices, SoftMax Pro 5 S.No. SMP500-16135-DPVW). Mean absorbance per minute $(A)$ was calculated for each dilution of different samples. Each plate had one blank well and one control well also. Percentage of inhibition of enzyme activity by a given concentration of sample was calculated by using the formula:

Per cent inhibition $=\left[\left(A_{\text {control }}-A_{\text {extract }}\right) / A_{\text {control }}\right] \times 100$

The percentage of inhibition obtained above was plotted vs. corresponding concentration of the extract of each sample. There were three replicates for each diluted concentration. The experiment was repeated for two more times. 
Fig. 1 Source of stem tissue (for methanolic extract preparation). a Young branches of mother plant (of 45-50 year age), bar $10 \mathrm{~cm}$; b young branches of seedlings/ micropropagated plants (of age 3-6 months), bar $2.5 \mathrm{~cm}$
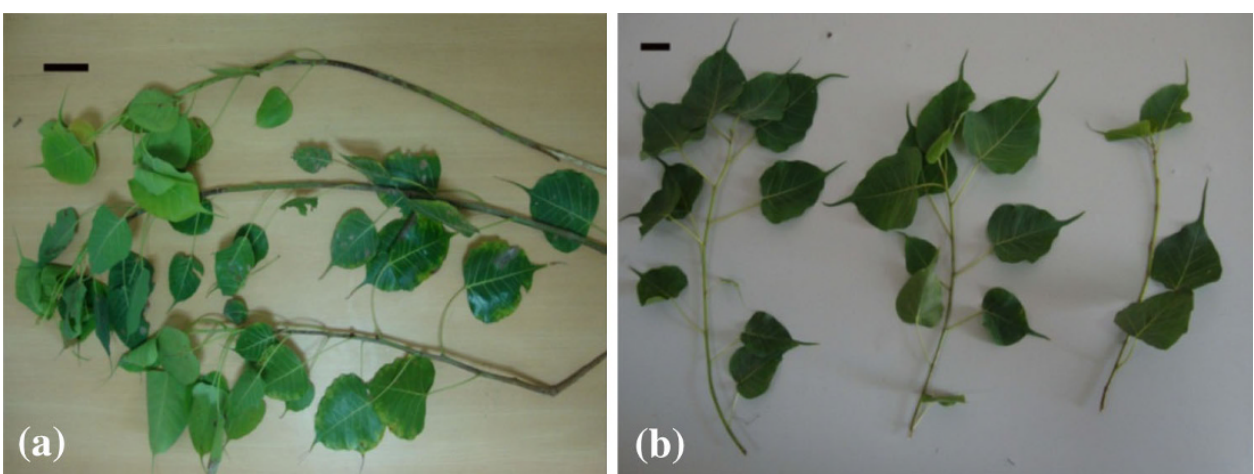

(b)
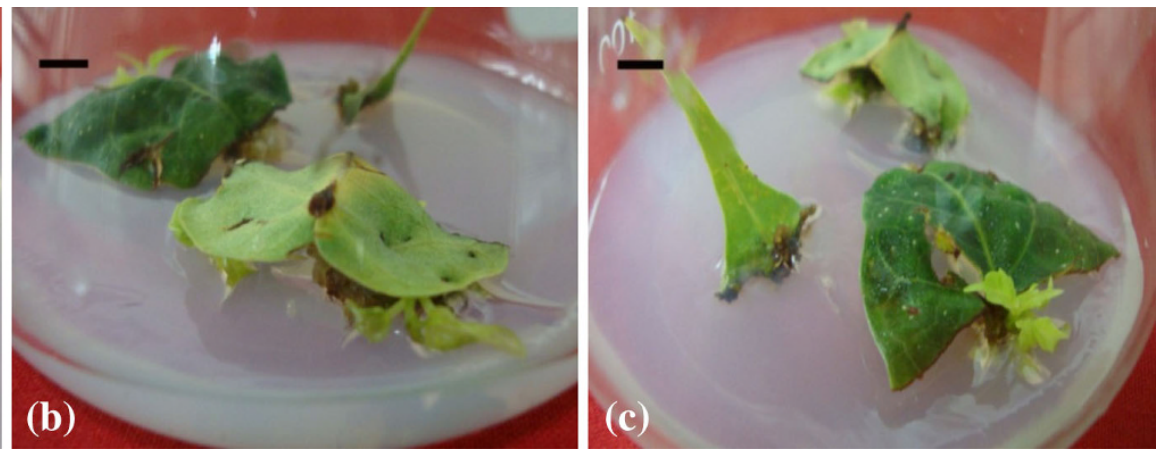

touching medium, bar $0.7 \mathrm{~cm}$; $\mathbf{c}$ horizontal orientation with abaxial surface touching the medium, bar $0.7 \mathrm{~cm}$

2 Induction of shoot buds/shoots from middle section of cultured in; a vertical orientation with one cut end inserted inside the medium, bar $0.4 \mathrm{~cm}$; b horizontal orientation with adaxial surface

\section{Calculating the $\mathrm{IC}_{50}$ value of each sample}

The obtained graph of each sample fitted perfectly in Logarithmic curve shape and was subjected to regression analysis using logarithmic equation. The $\mathrm{IC}_{50}$ value (i.e. the concentration at which the enzyme activity is inhibited by $50 \%$ ) was calculated with the obtained equation.

\section{Statistical analysis}

The experiments were set up in completely randomised design (CRD). The data were analysed by Analysis of Variance (ANOVA) followed by Duncan multiple range test (DMRT). Data analysis was carried out by using SPSS version 18.

\section{Results}

\section{Effect of explant orientation on shoot organogenesis}

The leaf sections, in all the orientations, exhibited shootbuds formation after 17-20 days of culture. Of the three types of cut leaf sections, middle section of the leaf performed better than the proximal or distal sections in each orientation (Table 1). Middle section responded with maximum frequency $(63.33 \%)$ in vertical orientation with cut portion inserted inside the medium, which was not significantly different to that obtained with horizontal orientation with adaxial surface $(60.00 \%)$ or abaxial surface $(56.67 \%)$ touching the medium (Table 1). Significantly higher number of shoots buds (4.83) which proliferated into equally higher number of shoots (4.57) with considerably more lengths $(2.67 \mathrm{~cm})$ was obtained with middle section of leaf in vertical orientation (Table 1). Distal sections and proximal sections responded poorly ( $40 \%$ or less than it) in all the three orientations. Regardless of the nature and orientation, shoots originated from the cut ends of leaf segments having direct contact with the medium (Fig. 2a-c).

Middle section of the leaves with cut portion inside the medium was selected for the subsequent studies and here onwards it will be referred as explant/leaf explant.

Effect of season on shoot organogenesis from leaf explant

With the same medium condition, percentage of response of leaf explant varied from a maximum of $66.67 \%$ (during the months of April, May, June, October and December) to 
(a)

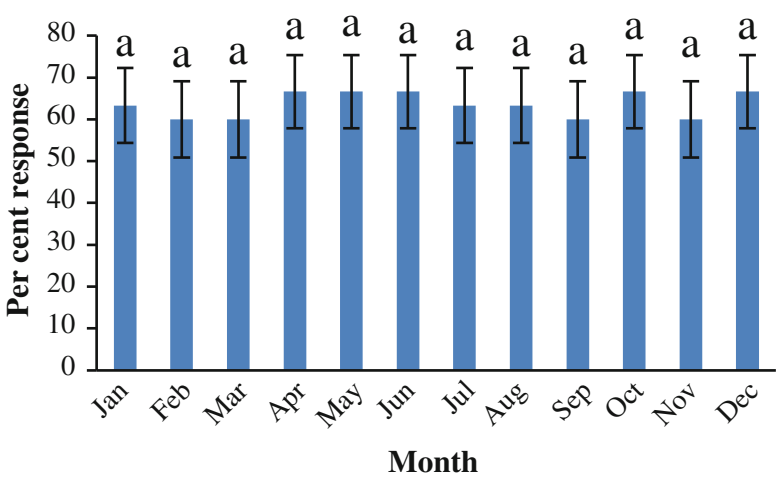

(b)

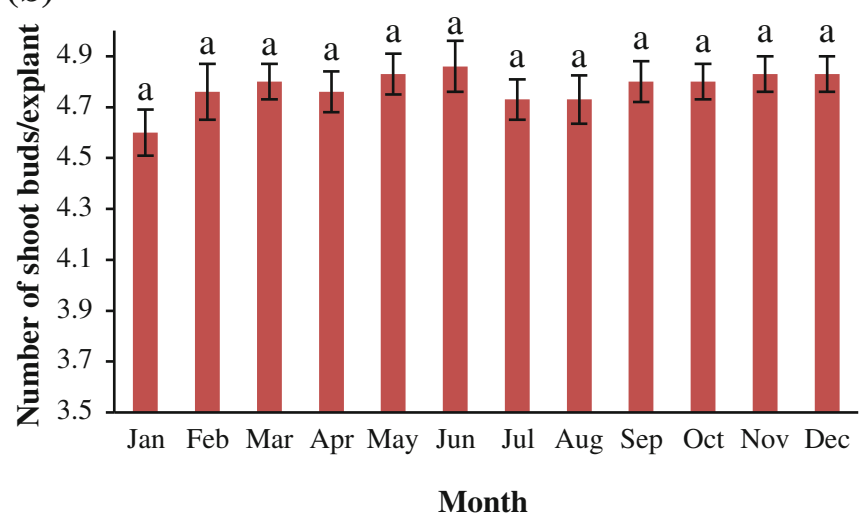

Fig. 3 Effect of month of explant collection on; a percent response of explant; $\mathbf{b}$ average number of shoot buds per leaf explant (observed after 28 days of culture)

Fig. 4 Shoot organogenesis from middle section of the leaf in vertical orientation, when cultured on MS medium having $5.0 \mathrm{mg} / \mathrm{l} \mathrm{BAP}$; a shoot buds as observed after 28 days of culture, bar $0.6 \mathrm{~cm}$; b shoots as observed after 60 days of initial culture, bar $0.5 \mathrm{~cm}$
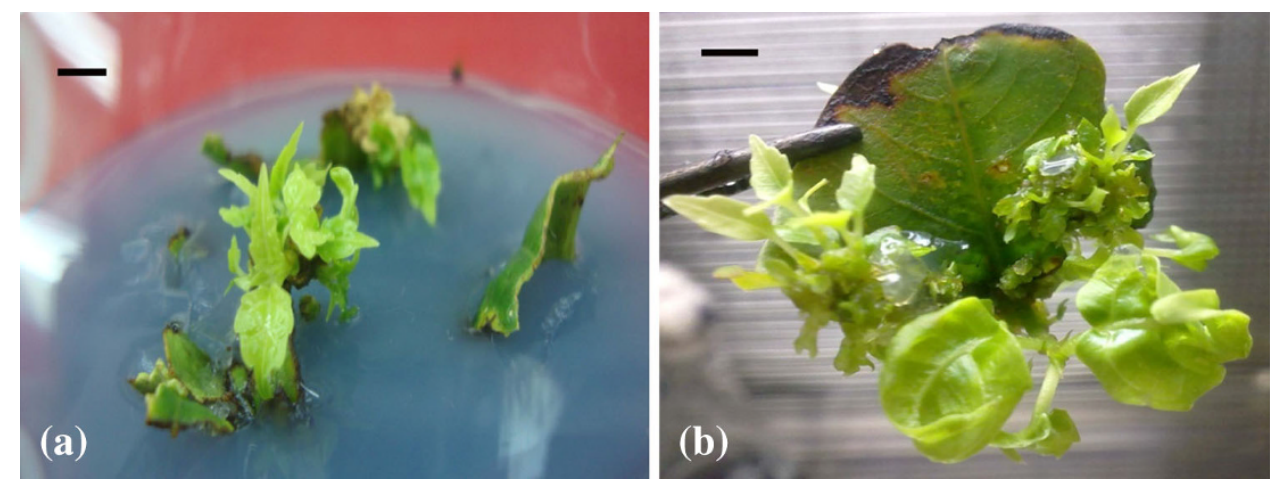

a minimum of $60 \%$ (during the months of February, March, September, November), the difference being statistically non-significant (Fig. 3a). Further, the maximum number of shoot buds per explant (4.86) was obtained for the month of June and this was not significantly different to that obtained during rest of the months (Fig. 3b).

Effect of plant growth regulators on direct shoot regeneration

Leaf explants responded differently to different concentrations of BAP and TDZ. With increase in concentrations of BAP from 1.0 up to $5.0 \mathrm{mg} / \mathrm{l}$, a continuous increase in percentage of response was observed, maximum being on $5.0 \mathrm{mg} / \mathrm{l}(100 \%)$, afterwards the frequency decreased. On the other hand, with increase in concentration of TDZ from 1.0 to $3.0 \mathrm{mg} / \mathrm{l}$, percentage of response continuously decreased; maximum was observed on $1.0 \mathrm{mg} / \mathrm{l}(63.33 \%)$ (Table 2). Further, beyond $1.5 \mathrm{mg} / \mathrm{l}$ of TDZ, shoot organogenesis was accompanied with extensive callus formation at the explant surface.

Addition of IAA $(0.5 \mathrm{mg} / \mathrm{l})$ in the medium already containing BAP or TDZ, making different combinations, significantly lowered the percentage of response (Table 2). A decrease in the number of shoot buds/shoots per explant, after addition of IAA to different concentrations of BAP, was also observed except for the combination of $0.5 \mathrm{mg} / \mathrm{l}$ IAA with $1.0 \mathrm{mg} / \mathrm{l}$ BAP which induced considerably higher number of shoots (7.27) per explant, though the percentage of response was low $(43.33 \%)$. Addition of IAA to different concentrations of TDZ induced a peculiar type of response, considerably higher number of shoot buds (7.07-12.23) were observed per explant but these shoot buds could not differentiate into full grown shoots.

Of the thirty-two PGR regimes screened, $5.0 \mathrm{mg} / \mathrm{l} \mathrm{BAP \text {, }}$ besides supporting maximum percent response (100\%), induced proliferation of maximum number of shoot buds (5.83) (as observed after 4 weeks of culture) (Fig. 4a) which later on turned into maximum number of shoots (7.93) with higher lengths $(2.97 \mathrm{~cm}$, on an average) (as observed after 60 days of initial culture) (Fig. 4b) (Table 2). Comparable number of shoots (7.27) was obtained on combination of $0.5 \mathrm{mg} / \mathrm{l} \mathrm{IAA}$ with $1.0 \mathrm{mg} / \mathrm{l}$ BAP, but as percentage of response on this particular combination was very low $(43.33 \%)$, this was not selected for further studies. 
Fig. 5 Shoots multiplication during sub-culturing on; a MS medium having $5.0 \mathrm{mg} / \mathrm{l} \mathrm{BAP}$, bar $0.7 \mathrm{~cm}$; b MS medium having $5.0 \mathrm{mg} / \mathrm{l} \mathrm{BAP}$ with additional supplementation of $200 \mathrm{mg} / \mathrm{l}$ glutamine, $150 \mathrm{mg} / \mathrm{l}$ adenine sulphate and $100 \mathrm{mg} / \mathrm{l}$ phloroglucinol, bar $0.5 \mathrm{~cm}$
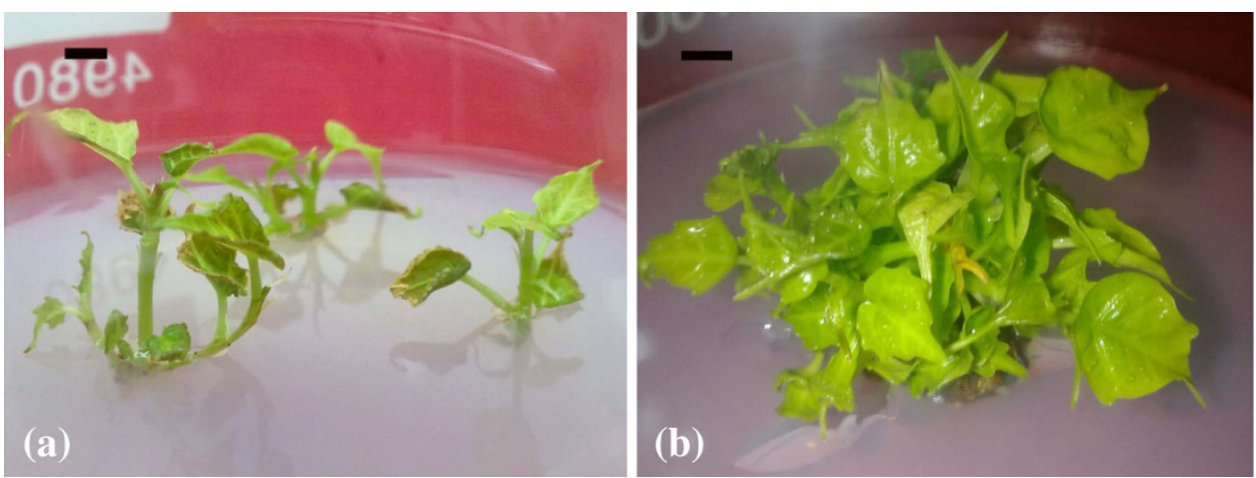

Shoot multiplication during sub-culturing

The shoots so obtained, when excised from the explant and cultured in a cluster of 2-3 shoots on the most suitable medium obtained above i.e. MS medium having $5.0 \mathrm{mg} / \mathrm{l}$ BAP (control), mild chlorosis of leaves and stem as well as curling and browning of leaves edges and early leaf fall (at low frequency) was observed (Fig. 5a). Further, the number of shoots obtained on this medium, at the end of fifth week, was also less (6.53) (Table 3). Lowering of BAP concentration to 2.5 and $1.0 \mathrm{mg} / \mathrm{l}$ further lowered the multiplication rate while health of shoots remained poor (Table 3). To improve quality of shoots as well as to enhance shoot multiplication rate, three additives were added in optimal concentration $(200 \mathrm{mg} / \mathrm{l}$ glutamine $+150 \mathrm{mg} / \mathrm{l}$ ADS $+100 \mathrm{mg} / \mathrm{l}$ phloroglucinol); optimisation of these additives being discussed in our previous report (Siwach and Gill 2011). Supplementation of these additives to each of the three concentration of BAP significantly increased the shoot multiplication rate as well as improved the quality of the shoots (Table 3). Of the three concentrations of BAP, significantly higher number of shoots (24.37) was obtained when this combination of glutamine, ADS and phloroglucinol was supplemented to $5.0 \mathrm{mg} / \mathrm{l} \mathrm{BAP}$ (Fig. 5b) indicating the suitability of higher cytokinin concentration even during repeated sub-culturing. The shoots so obtained were isolated after 5 weeks of culture and were sub-cultured on this medium and the process was repeated 4-5 times, before subjecting the individual shoot to rooting.

In vitro rooting, acclimatisation and transplantation

The efficient in vitro rooting of the shoots, regenerated above, was obtained on MS medium supplemented with $2.0 \mathrm{mg} / \mathrm{l}$ indole butyric acid (IBA) along with $0.1 \mathrm{mg} / \mathrm{l}$ IAA, with a frequency of $95 \%$, as discussed in earlier report (Siwach and Gill 2011) (Fig. 6). The plantlets were successfully acclimatised (Fig. 7) and transferred to field

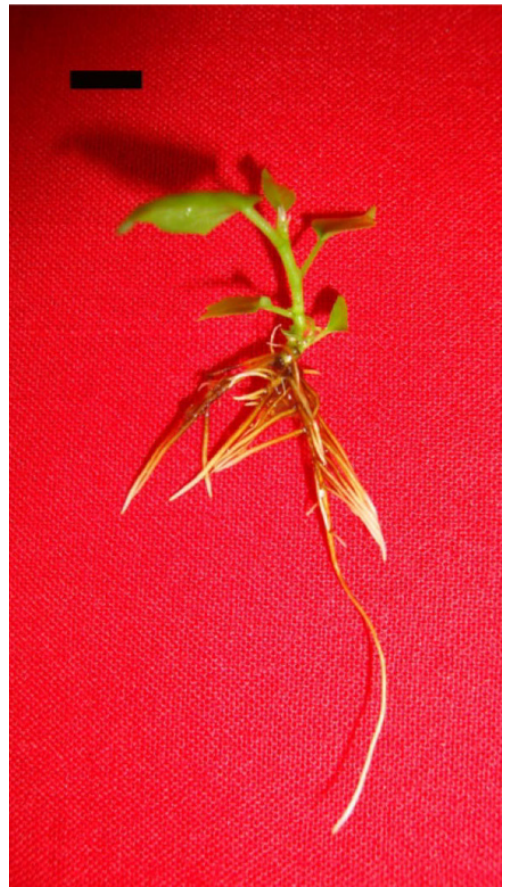

Fig. 6 In vitro rooting of micro-shoots obtained on semi-solid MS medium supplemented with $2.0 \mathrm{mg} / \mathrm{l} \mathrm{IBA}$ and $0.1 \mathrm{mg} / \mathrm{l} \mathrm{IAA,} \mathrm{bar}$ $1.0 \mathrm{~cm}$

conditions (Fig. 8) with a survival rate of $90 \%$ on conditions reported earlier (Siwach and Gill 2011).

\section{Checking the clonal fidelity of micropropagated plants}

Out of 20 RAPD primers, amplification with reproducible band pattern was obtained with 13 (primers 1, 2, 3, 4, 9, 11, $12,13,14,17,18,19,20$ ); rest seven primers either did not yield amplification or gave poor non-reproducible band pattern (Table 4). With these thirteen primers monomorphic band pattern was observed in the six randomly selected micropropagated plants and the MP sample, which confirmed the clonal nature of micropropagated plants (Table 4). 


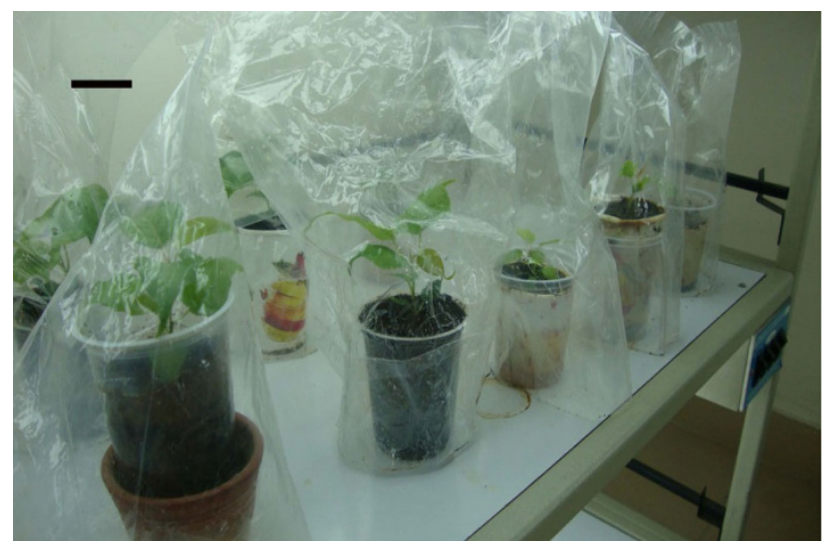

Fig. 7 Acclimatisation of transplanted plants under culture room conditions, bar $5 \mathrm{~cm}$

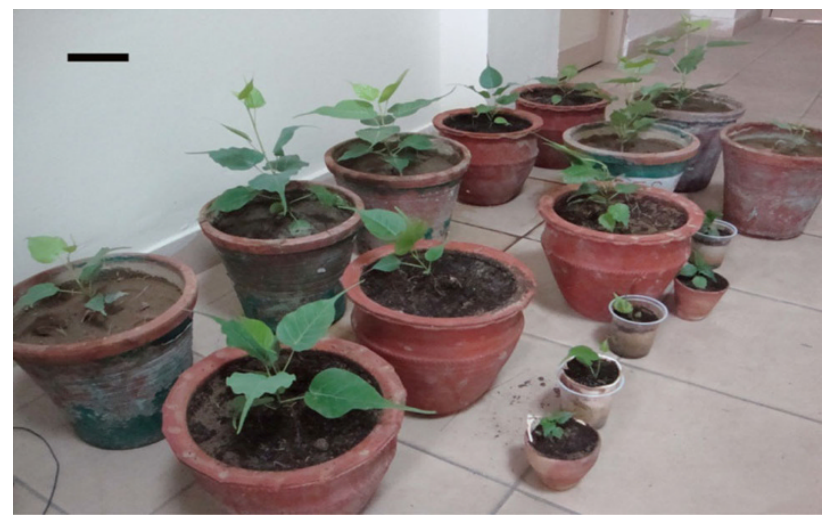

Fig. 8 Successful acclimatised, potted plants of different age, bar $10 \mathrm{~cm}$

The selected three seedlings exhibited monomorphic band profile among themselves as well as the MP and selected micropropagated plants, when amplified with nine primers-3, 4, 12, 13, 14, 17, 18, 19 and 20 (Table 4). With rest four primers $(1,2,9,11)$, the seedlings yielded different band amplification profile. With primer $1, \mathrm{Se}-2_{4 \mathrm{M}}$ yielded monomorphic band pattern with MP (single band of $500 \mathrm{bp}$ ), while one polymorphic band of 670 and $600 \mathrm{bp}$ was observed for $\mathrm{Se}-1_{6 \mathrm{M}}$ and $\mathrm{Se}-3_{4 \mathrm{M}}$ respectively. With primer 2, a monomorphic band of $700 \mathrm{bp}$ was observed in all the three seedlings (monomorphic with MP and microproagated plants also), while polymorphic band of $840 \mathrm{bp}$ was observed for Se- $1_{6 \mathrm{M}}$. The MP and micropropagate plants also yielded a band of $1,200 \mathrm{bp}$ with primer 2 and this band was absent in all the three seedlings. The amplification with primer 9 yielded 3 monomorphic bands of 240, 340, $440 \mathrm{bp}$ size in MP, micropropagated plants, Se- $2_{4 \mathrm{M}}$, and Se- $3_{4 \mathrm{M}}$, while two polymorphic bands of 590 and $610 \mathrm{bp}$ size were found only in the three seedlings, while a polymorphic band of $300 \mathrm{bp}$ was observed only in Se-1 $1_{6 \mathrm{M}}$ (Fig. 9). Likewise, with primer
11, monorphic bands of sizes $350,410,600,700 \mathrm{bp}$ were found in all the ten samples, polymorphic band of $150 \mathrm{bp}$ was found in $\mathrm{Se}-1_{6 \mathrm{M}}$ and $\mathrm{Se}-3_{4 \mathrm{M}}$ and polymorphic band of 900 was observed only in Se-1 ${ }_{6 \mathrm{M}}$ (Fig. 9).

\section{AChE inhibitory assay}

Different concentration of the extracts, of the selected eight samples (MP, Se- $1_{6 \mathrm{M}}, \mathrm{Se}-2_{4 \mathrm{M}}, \mathrm{Se}-3_{4 \mathrm{M}}, \mathrm{MiP}-1_{3 \mathrm{M}}, \mathrm{MiP}-2_{3 \mathrm{M}}$, MiP- $3_{6 \mathrm{M}}$ and MiP-4 $6 \mathrm{M}$ ) inhibited the AChE enzyme by different degree, as revealed by AChE inhibitory assay (Fig. 10). The inhibitions obtained with different samples could be categorised in three groups: low (5-20\%), moderate $(20-50 \%)$ and good $(50-100 \%)$ inhibition. MP exhibited low inhibition at low concentrations of $20 \mu \mathrm{g} / \mathrm{ml}$ $(15.35 \%)$, moderate inhibition at 40 and $60 \mu \mathrm{g} / \mathrm{ml}(35.75$ and $46.48 \%$, respectively), while at concentration of 80 and $100 \mu \mathrm{g} / \mathrm{ml}$, good inhibition of 55.80 and $61.58 \%$, respectively, was observed (Fig. 10a). The $\mathrm{IC}_{50}$ value obtained with the mother plant sample was $66.49 \mu \mathrm{g} / \mathrm{ml}$ (Table 5). The 6 months' aged seedlings $\left(\mathrm{Se}-1_{6 \mathrm{M}}\right)$ exhibited very poor ability $(<20 \%)$ to inhibit AChE enzyme at all the concentrations; the highest concentration of $100 \mu \mathrm{g} / \mathrm{ml}$, could inhibit the AChE enzyme by only $16.86 \%$ (Fig. 10b). The $\mathrm{IC}_{50}$ value obtained for Se was very high $(20,538.30 \mu \mathrm{g} / \mathrm{ml})$ (Table 5). Similar observations were made for two other seedlings of 4 months age; $\mathrm{IC}_{50}$ for Se- $2_{4 \mathrm{M}}$ and Se- $3_{4 \mathrm{M}}$ being $19,341.03$ and $24,281.70 \mu \mathrm{g} / \mathrm{ml}$, respectively. Contrary to the seedlings, the plants obtained by micropropagation, showed very effective AChE inhibitory activity. At each concentration, the methanolic extracts of all the four selected micropropagated plants exhibited AChE inhibitory activity quite similar to that obtained with MP; good inhibition (more than $50 \%$ ) was observed at concentrations of 80 and $100 \mu \mathrm{g} /$

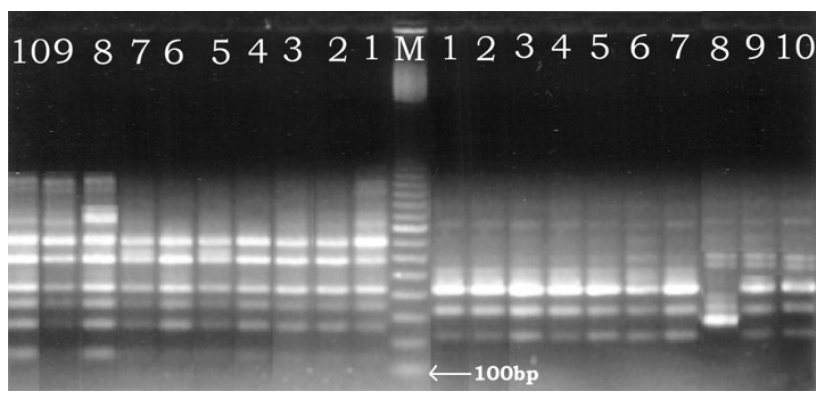

Fig. 9 A representative RAPD reaction for checking the clonal fidelity of micropropagated plants and seedling. M: $100 \mathrm{bp}$ ladder (GE Healthcare Life Sciences), Samples on the right of the ladder were amplified with primer 9 (GGGTTTCGCC) and samples on the left of ladder were amplified using primer 11 (TATTCGGCGT). Lane 1 mother plant (MP); lane 2-7 micropropagated plants of 1, 2, 4, 5, 6, 7 months age respectively; lane 8 seedling of 6 months age (Se- $1_{6 \mathrm{M}}$ ); lane 9 seedling of 4 months age $\left(\mathrm{Se}-2_{4 \mathrm{M}}\right)$; lane 10 another seedling of 4 months age $\left(\mathrm{Se}-3_{4 \mathrm{M}}\right)$ 

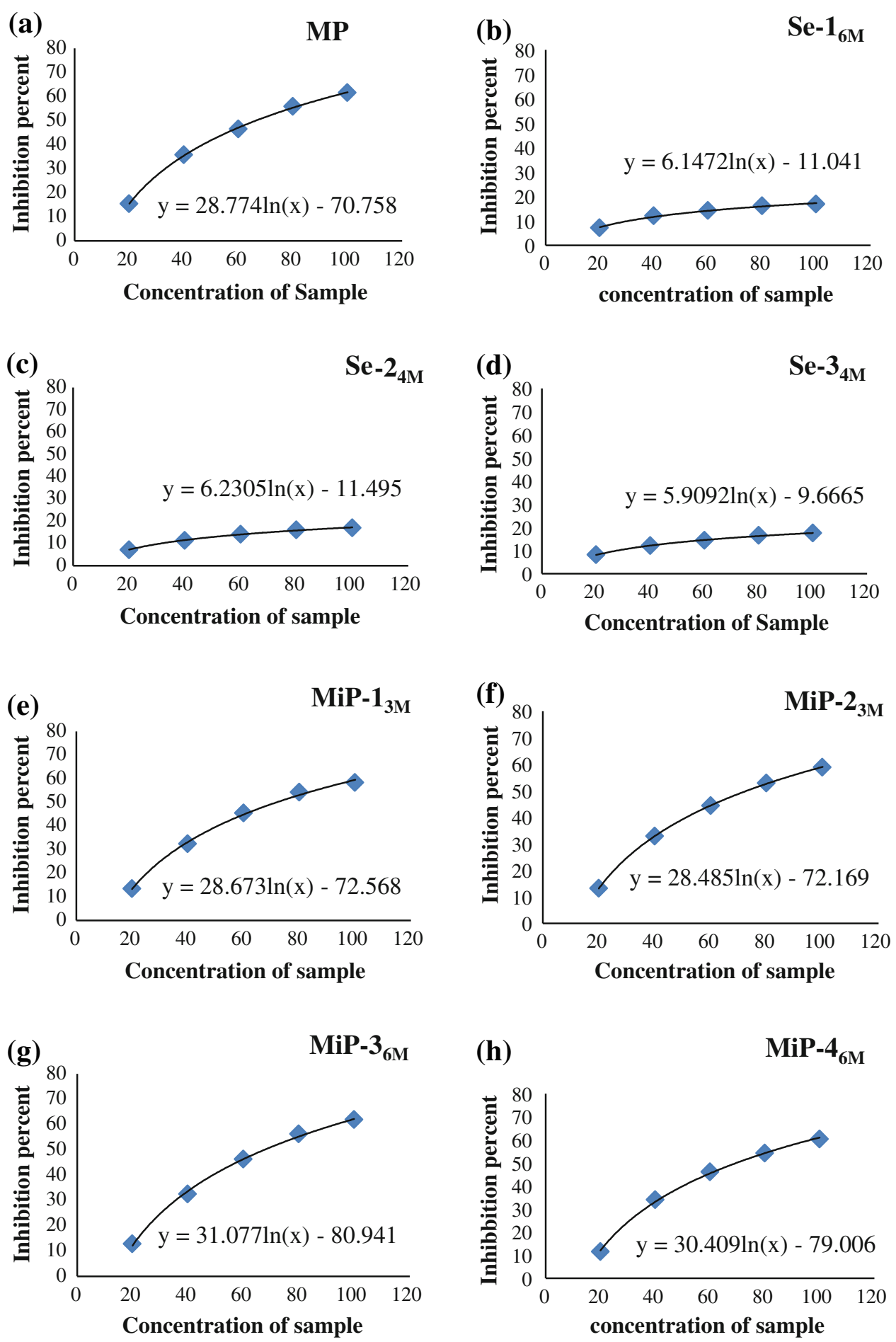

Fig. 10 Logarithmic curves representing the percentage of inhibition of AChE enzyme by respective concentrations of different samples viz. a MP, b Se- $1_{6 \mathrm{M}}$, c Se- $2_{4 \mathrm{M}}$, d Se- $3_{4 \mathrm{M}}$, e MiP- $1_{3 \mathrm{M}}$, f MiP- $2_{3 \mathrm{M}}, \mathbf{g ~ M i P}-3_{6 \mathrm{M}}, \mathbf{h ~ M i P}-4_{6 \mathrm{M}}$

$\mathrm{ml}$ (Fig. 10c-f). In fact, the four selected micropropagated plants, MiP- $1_{3 \mathrm{M}}, \mathrm{MiP}-2_{3 \mathrm{M}}, \mathrm{MiP}-3_{6 \mathrm{M}}$ and MiP- $4_{6 \mathrm{M}}$ exhibited $\mathrm{IC}_{50}$ values of $71.87,72.91,67.65$ and $69.65 \mu \mathrm{g} / \mathrm{ml}$, which was quite similar to that obtained with MP $(66.49 \mu \mathrm{g} / \mathrm{ml})$ (Table 5).

\section{Discussions}

A highly efficient, season-independent, micropropagation protocol has been developed for $F$. religiosa $\mathrm{L}$. using leaf explants, followed by comparative AChE inhibitory 
Table $5 \mathrm{IC}_{50}$ values of mother plant (MP), three randomly selected seedlings (Se) and four randomly selected micropropagated plants (MiP) of $F$. religiosa, as calculated by the acetylcholinesterase inhibitory (AChEI) activity assay

\begin{tabular}{llr}
\hline & Sample & IC $_{50}$ value* $(\mu \mathrm{g} / \mathrm{ml})$ \\
\hline 1 & MP (mother plant) & $66.49 \pm 01.39$ \\
2 & Se- $1_{6 \mathrm{M}}$ (of 6 months age) & $20,538.46 \pm 1.22$ \\
3 & Se-2 4 (of 4 months age) & $19,341.03 \pm 0.47$ \\
4 & Se-3 $3_{4 \mathrm{M}}$ (of 4 months age) & $24,281.70 \pm 0.32$ \\
5 & MiP-1 $_{3 \mathrm{M}}$ (of 3 months age) & $71.87 \pm 01.28$ \\
6 & MiP-2 $_{3 \mathrm{M}}$ (of 3 months age) & $72.91 \pm 00.12$ \\
7 & MiP-3 6 (of 6 months age) & $67.65 \pm 00.41$ \\
8 & MiP-4 6 (of 6 months age) & $69.65 \pm 00.42$ \\
\hline
\end{tabular}

*Values are means from 3 repeat experiments (each experiment further having three replicates) $\pm \mathrm{SE}$

activity assay of the in vitro raised and conventionally grown plants, for the first time during the present study.

A significant effect of nature and orientation of leaf segments was observed on direct shoot organogenesis; middle section of leaves with cut end inserted inside the medium was found most suitable (Table 1). The orientation of leaf explant has also been reported to play an important role in the micropropagation of some other plants like Marion Blackberry (Meng et al. 2004). In vitro response of explants from woody perennials is reported to be strongly influenced by season of explant collection (Debergh and Maene 1984; Debergh and Read 1991). Such an observation has also been reported for the nodal explants of F. religiosa (Siwach et al. 2011). However, during the present study, the percentage of response as well as average number of shoots buds per leaf explant was found nearly consistent (with non-significant differences) during all the 12 months of the year (Fig. 3). Such report, mentioning leaves as explants with no seasonal constraints, did not exist previously for any other plant species. One of the possible explanations is that the axillary and apical meristematic cells, of the perennial trees, are genetically directed to divide actively during the active growth season, and this periodic growth direction may not be there with the differentiated tissues like leaves, though to conclude this fact, more studies are needed.

The optimal PGR requirement for direct shoot regeneration from nodal segments of $F$. religiosa has been found different by different groups. Deshpande et al. (1998) reported $5 \mathrm{mg} / \mathrm{l} \mathrm{BAP}$ as suitable for initial bud break and $1.0 \mathrm{mg} / \mathrm{l} \mathrm{BAP}$ as for further shoot proliferation, Hassan et al. (2009) found $0.5 \mathrm{mg} / \mathrm{l} \mathrm{BAP}$ in combination with $0.1 \mathrm{mg} / 1 \mathrm{IAA}$ as most suitable while Siwach and Gill (2011) found combination of $1.0 \mathrm{mg} / \mathrm{l} \mathrm{BAP}$ and $0.5 \mathrm{mg} / \mathrm{l}$ IAA best for shoot induction and multiplication. During the present study, with leaves' segments as explants, a different PGR requirement was observed for direct shoot regeneration. Of the two cytokinins, BAP was found better than TDZ for shoot induction and proliferation (Table 2). Amongst various concentrations of BAP, alone as well as in combination with $0.5 \mathrm{mg} / \mathrm{l} \mathrm{IAA}$, used during the present study, BAP at $5.0 \mathrm{mg} / \mathrm{l}$ was found most suitable for percentage of response $(100 \%)$ as well as for inducing maximum number of shoots per explant (7.93) (Table 2). The suitability of higher level of BAP for shoot induction and proliferation from the leaf explant has also been documented for Piper nigram (Ahmad et al. 2010) and Brassica rapa (Abbasi et al. 2011). Though combination of $1.0 \mathrm{mg} / \mathrm{l} \mathrm{BAP}$ and $0.5 \mathrm{mg} / \mathrm{l}$ IAA also induced considerably high number of shoots (7.27), it could not be considered as suitable medium because of poor response $(43.33 \%)$. Induction of high number of shoots on this particular medium could be attributed to low cytokinin to auxin ratio but the reason for poor response on it could not be explained with present data and literature available. The low cytokinin to auxin ratio has also been reported earlier as the most suitable ratio for efficient shoot induction from the nodal explants of F. religiosa (Hassan et al. 2009; Siwach and Gill 2011).

Addition of IAA in the medium having BAP or TDZ was found inhibitory for percentage of response. Similar findings of inhibitory effect of combination of auxin and cytokinin for shoot organogenesis frequency have also been reported for some other plant species (Ahmad et al. 2010; Abbasi et al. 2011). Combination of IAA and TDZ was found very efficient in initial shoot bud induction, however, these buds could not grow into shoots and remained stunted. Similar observation was observed with TDZ alone in the medium, during the direct shoot organogenesis from nodal explants of $F$. religiosa (Siwach and Gill 2011). TDZ is a substituted phenyl urea ( $N$-phenyl1,2,3-thidiazol-5-yl urea) that has immense potential as a cytokinin in shoot organogenesis in a large number of plant systems, especially in the woody species (Mansouri and Preece 2009). On the other hand, some studies have reported the negative impact of TDZ on shoot proliferation (Feng et al. 2010), however how this effect was further augmented by addition of $0.5 \mathrm{mg} / \mathrm{l}$ IAA during the present study could not be explained by the existing literature.

The shoots when excised from the explant and subcultured on same medium (BAP $5.0 \mathrm{mg} / \mathrm{l}$ ) exhibited chlorosis of stem and leaves, curling and browning of leaves edges as well as early leaf fall (Fig. 5a). Such observations were also made during the shoot proliferation from nodal segments of F. religiosa (Siwach and Gill 2011) as well as for some other plant species (Husain et al. 2008). The suitability of a particular combination of three additives (200 mg/l glutamine+ $150 \mathrm{mg} / \mathrm{l}$ ADS $+100 \mathrm{mg} / \mathrm{l}$ phloroglucinol) for overcoming these problems has been reported 
and discussed well earlier (Siwach and Gill 2011). During present study, higher concentration of BAP $(5.0 \mathrm{mg} / \mathrm{l})$ was also found supportive for shoot multiplication during repeated sub-culturing, as compared to lower one (Table 3). This was contrary to a general observation where cytokinin, at high concentration, favours shoot induction while lowering of concentration is optimal for subsequent shoot proliferation (Deshpande et al. 1998).

The protocol so developed as discussed above is different and more efficient from the existing protocols for micropropagation of $F$. religiosa. Jaiswal and Narayan (1985) have reported shoot regeneration via indirect organogenesis through callus phase initiated from nodal explants of $F$. religiosa, maximum number of 6-10 shoots being obtained from a callus piece. Likewise Narayan and Jaiswal (1986) have reported differentiation of plantlets, 5-10 in number, from leaf callus of $F$. religiosa. Micropropagation via the callus phase has chances of somaclonal variations and so cannot be said to be clonal propagation. Direct shoot regeneration in $F$. religiosa $\mathrm{L}$. has been reported by Deshpande et al. (1998) and in their study, maximum of 5-6 shoots were obtained from a single explant which may be considered as low regeneration rate for a commercially efficient and economically viable micropropagation system. Further no observation has been made for shoot multiplication during repeated sub-culturing, no mention of any observation/problem common to tissue culture of higher age woody perennials, has been made. Hassan et al. (2009) have reported a comparative high rate of multiplication (10-15 shoots per explant) from nodal explants of $F$. religiosa but still the study lacked the observations regarding health of the shoots during continuous sub-culturing process. An efficient micropropagation protocol for $F$. religiosa, using nodal segments as explants (giving 35 shoots per explant) was reported by us earlier (Siwach and Gill 2011) but culture initiation part had to be restricted to a particular time-period of the year as the response of nodal segments was found to be strongly affected by the season of explant collection (Siwach et al. 2011). The present study observed no effect of season on the in vitro response of mature leaves segments of F. religiosa and hence leaves were concluded as suitable explants for obtaining season independent micropropagation protocol. Leaves have been taken as explants for micropropagation of many other woody plant species like Prunus serotina (Liu and Pijut 2008), Elaeocarpus robustus (Rahman et al. 2003) but weather the response is affected by the season of leaf explant collection has not been studied. Such a finding will be of great importance for developing commercial micropropagation protocol of woody perennials.

The RAPD molecular marker analysis was found successful for checking the genetic fidelity of plants, during the present study. Out of twenty primers, five primers (primers 5, 6, 7, 15, 16) resulted in no amplification in all the samples probably because of lack of formation of stable primer template structure during PCR reaction. Two primers (8 and 10) did not yield stable and consistent amplification profile for any of the selected samples indicating towards the redundancy of complementary sites for these two primers. The 13 primers (primers 1, 2, 3, 4, 9, 11, $12,13,14,17,18,19,20)$, which resulted in stable amplification in all the samples, exhibited monomorphism among the selected micropropagated plants and MP confirming the clonal nature of these plants. Out of these 13, amplification with four primers (1, 2, 9, 11), exhibited polymorphism among seedlings and MP. Such an observation supports the occurrence of genetic changes during gamete formation and so confirms the propagation via seeds as non-clonal way of propagation. RAPD markers have also been used successfully to assess genetic stability among micropropagated plants of a number of species earlier e.g. Ribes nigrum L. (Khan and Spoor 2001).

The 45-50 years old $F$. religiosa tree, used as mother plant during the present study was found to possess higher AChE inhibitory activity $\left(\mathrm{IC}_{50}\right.$ of $\left.66.49 \mu \mathrm{g} / \mathrm{ml}\right)$ than that reported for $F$. religiosa $\left(\mathrm{IC}_{50}\right.$ of $\left.73.69 \mu \mathrm{g} / \mathrm{ml}\right)$ by Vinutha et al. (2007). It can be attributed to the difference in the genotype, physiological state as well as environmental conditions between the samples of the two studies.

The micropropagated plants of 3 and 6 months age were found to exhibit AChE inhibitory activity quite similar to that of mother plant of 45-50 years age (Fig. 10). Contrarily, seedling of the 6 months age and 4 months age exhibited very poor ability to inhibit AChE enzyme. The normal course of development observed with perennial trees include the nil or poor production of secondary metabolites during primary years of growth and development and generally after 20-25 years of growth, secondary metabolites synthesis is accelerated leading to higher level of these metabolites in different parts of the tree (Kulkarni 2000). This could explain the huge difference in the AChE inhibitory activity of the higher age $\mathrm{MP}\left(\mathrm{IC}_{50}-66.49 \mu \mathrm{g} /\right.$ $\mathrm{ml}), 6$ months old seedling Se-1 ${ }_{6 \mathrm{~m}}(20,538.30 \mu \mathrm{g} / \mathrm{ml})$ and 4 months old seedlings-Se- $2_{4 \mathrm{M}}(19,341.03 \mu \mathrm{g} / \mathrm{ml})$, Se$3_{4 \mathrm{M}}(24,281.70 \mu \mathrm{g} / \mathrm{ml})$. The explants, when isolated from the higher age plants, have secondary metabolic pathways genes in the active mode (i.e. switched on state) and these genes generally remain in same state in the plants, regenerated from these explants (Kulkarni 2000). So, in vitro raised plants (from explants of higher age plant) start producing secondary metabolites much earlier than the plants obtained by seed germination and are better source for pharmaceutical application (Gurel et al. 2011; Rao et al. 2011; Jiang et al. 2012). This is the possible explanation of obtaining higher AChE inhibitory activity in the 
methanolic extracts of 3 and 6 months aged micropropagated plants, compared to that in the 4 and 6 months old seedling. Such observation is of great significance for exploiting the pharmaceutical applications of $F$. religiosa towards AD treatment as it rules out the need of waiting for so many years to let the plant start secondary metabolites synthesis and hence avoids the issues of social, environmental and religious concerns and gives an alternative for large scale commercial production.

\section{Conclusion}

In conclusion, our studies demonstrated that the leaves explant can be a better alternative to apical or nodal explants for developing a season independent regeneration protocol. Higher concentration of BAP $(5.0 \mathrm{mg} / \mathrm{l})$ was most suitable for direct shoot regeneration as well as shoot multiplication. During repeated sub-culturing, the medium needed to be additionally supplemented with ADS $(150 \mathrm{mg} /$ 1), glutamine $(200 \mathrm{mg} / \mathrm{l})$ and phloroglucinol $(100 \mathrm{mg} / \mathrm{l})$ to overcome the problems of chlorosis and leaf fall. The micropropagated plants were genetically stable as was revealed by RAPD analysis of randomly selected plants of different age. Acetylcholinesterase inhibitory (AChEI) activity of micropropagated plants was quite effective, similar to that of mother plant while 6 months old seedling performed very poorly towards enzyme inhibition. The findings of present study give an alternative source for exploiting AChEI activity at large scale and will be of great use in developing new solutions to Alzheimer disease.

Acknowledgments The award of junior research fellowship to Anita Rani Gill under the 'Rajiv Gandhi National Fellowship Scheme' by the 'University Grants Commission' New Delhi, India is acknowledged. We also acknowledge the financial assistance provided by Ch. Devi Lal University, Sirsa, Haryana, India, for all the laboratory requirements.

Conflict of interest It is declared that no conflict of interest is associated with the publication of this paper.

Open Access This article is distributed under the terms of the Creative Commons Attribution License which permits any use, distribution, and reproduction in any medium, provided the original author(s) and the source are credited.

\section{References}

Abbasi BH, Khan M, Guo B, Bokhari SA, Khan MA (2011) Efficient regeneration and antioxidative enzyme activities in Brassica rapa var. turnip. Plant Cell Tiss Org Cult 105:337-344

Ahmad N, Fazal H, Abbasi BH, Rashid M, Mahmood T, Fatima N (2010) Efficient regeneration and antioxidant potential in regenerated tissues of Piper nigrum L. Plant Cell Tiss Org Cult 102(1):129-134
Ambike SH, Rao MRR (1967) Studies on a phytosterolin from the bark of Ficus religiosa Part-I. Ind J Pharm 29:91-92

Bertaccini G (1982) Substance P. In: Handbook of Experimental Pharmacology, vol 59, no. 2, Springer, Berlin, pp 85-105

Darvesh S, Walsh R, Kumar R, Caines A, Roberts S, Magee D, Rockwood K, Martin E (2003) Inhibition of human cholinesterases by drugs used to treat Alzheimer disease. Alzheimer Dis Assoc Disord 17:117-126

Debergh P, Maene L (1984) Pathological and physiological problems related to the in vitro culture of plants. Parasitica 40:69-75

Debergh PC, Read PE (1991) Micropropagation. In: Debergh PC, Zimmerman RH (eds) Micropropagation, technology and application. Kluwer Academic Publishers, The Netherlands, pp 1-13

Deshpande SR, Josekutty PC, Prathapasenam G (1998) Plant regeneration from axillary buds of a mature tree of Ficus religiosa L. Plant Cell Rep 17(6-7):571-573

Ellman GL, Courtney KD, Andres V, Featherstone RM (1961) A new and rapid colorimetric determination of acetylcholinesterase activity. Biochem Pharmacol 7:88-95

Feng JCYXM, Shang XL, Li JD, Wu YX (2010) Factors influencing efficiency of shoot regeneration in Ziziphus jujube Mill 'Huizao'. Plant Cell Tiss Org Cult 101:111-117

Gurel E, Yucesan B, Aglic E, Gurel S, Verma S, Sokmen M, Sokmen A (2011) Regeneration and cardiotonic glycoside production in Digitalis Davisiana Heywood (Alanya Foxglove). Plant Cell Tiss Org Cult 104:217-255

Hassan AKMS, Afroz F, Jahan MAA, Khatun R (2009) In vitro regeneration through apical and axillary shoot proliferation of Ficus religiosa L.-A multipurpose woody medicinal plant. Plant Tiss Cult Biotechnol 19(1):71-78

Husain MK, Anis M, Shahzad A (2008) In vitro propagation of a multipurpose leguminous tree (Pterocarpus marsupium Roxb.) using nodal explants. Acta Physiol Plant 30:353-359

Ingkaninan K, Best D, Heijden VD, Hofte AJP, Karabatak B, Irth H, Tjaden UR, Greef VD, Verpoorte R (2000) High-performance liquid chromatography with on-line coupled UV, mass spectrometric and biochemical detection for identification of acetylcholinesterase inhibitors from natural products. J Chromatrogr A 872:61-73

Jaiswal VS, Narayan P (1985) Regeneration of plantlets from the callus of stem segments of adult plants of Ficus religiosa L. Plant Cell Rep 4:256-258

Jiang W, Chen L, Pan Q, Qiu Y, Shen Y, Fu C (2012) An efficient regeneration system via direct and indirect organogenesis for the medicinal plant Dysosma versipellis (Hance) M. Cheng and its potential as a podophyllotoxin source. Acta Physiol Plant 34:631-639

Khan S, Spoor W (2001) Evaluation of genetic stability in the Blackcurrent plants regenerated via micropropagation using RAPD-PCR technique. Pak J Bot 33(4):411-417

Kirana H, Aggrawal SS, Srinivasan BP (2009) Aqueous extract of Ficus religiosa Linn: reduces oxidative stress in experimentally induced type 2 diabetic rats. Indian J Exp Biol 47:822-826

Kulkarni AA (2000) Micropropagation and secondary metabolite studies in Taxus spp. and Withania somnifera (L) Dunal. Ph.D. Thesis submitted to the University of Pune

Liu X, Pijut M (2008) Plant regeneration from in vitro leaves of mature black cherry (Prunus serotina). Plant Cell Tiss Org Cult 94:113-123

Mansouri K, Preece JE (2009) The influence of plant growth regulators on explant performance bud break and shoot growth from large stem segments of Acer saccharinum L. Plant Cell Tiss Org Cult 99:313-318

McCown BH (2000) Recalcitrance of woody and herbaceous perennials plants: dealing with genetic predetermination. In Vitro Cell Dev Biol Plant 36:149-154 
Meng R, Chen THH, Fin CE, Li Y (2004) Improving in vitro plant regeneration from leaf and petiole explants of 'Marion' blackberry. HortScience 39(2):316-320

Murashige T, Skoog F (1962) A revised medium for rapid growth and bioassays with tobacco tissue cultures. Plant Physiol 15:473-497

Narayan P, Jaiswal VS (1986) Differentiation of plantlets from leaf callus of $F$. religiosa L. Indian J Exp Biol 24:193-194

Pandit R, Phadke A, Jagtap A (2010) Antidiabetic effect of Ficus religiosa extract in streptozotocin-induced diabetic rats. J Ethnopharmacol 128:462-466

Pattnaik SK, Chand PK (1996) In vitro propagation of the medicinal herbs Ocimum americanum L O canum Sims (hoary basil) Ocimum sanctum L (holy basil). Plant Cell Rep 15:846-850

Rahman MM, Amin MN, Azad MA, Begum F, Karim MK (2003) In vitro rapid regeneraion of plantlets from leaf explant of native-olive (Elaeocarpus robustus Roxb.). J Biol Sci 3(8):718-725

Rao K, Chodisetti B, Gandi S, Mangamoori LN, Giri A (2011) Direct and indirect organogenesis of alpinia galanga and the phytochemical analysis. Appl Biochem Biotechnol 165:1366-1378

Sancheti S, Sancheti S, Um BH, Seo SY (2009) 1, 2, 3, 4, 6-pentaOgalloyl-D-glucose: a cholinesterase inhibitor from Terminalia chebula. S Afr J Bot doi:10.1016/j.sajb.2009.11.006

Sanghai-Maroof MA, Soliman K, Jorgensen RA, Allard RW (1984) Ribosomal DNA spacer length polymorphisms in barley: mendelian inheritance, chromosomal location and population dynamics. Proced Natl Acad Sci 81:8014-8018

Singh D, Goel RK (2009) Anticonvulsant effect of Ficus religiosa: role of serotonergic pathways. J Ethnopharmacol 123(2): 330-334
Singh D, Singh B, Goel RK (2011) Traditional uses, phytochemistry and pharmacology of Ficus religiosa: a review. J Ethnopharmacol 134(3):565-583

Siril EA, Dhar U (1997) Micropropagation of mature Chinese tallow tree (Sapium sebiferum Roxb). Plant Cell Rep 16:637-640

Siwach P, Gill AR (2011) Enhanced shoot multiplication in Ficus religiosa $\mathrm{L}$. in the presence of adenine sulphate, glutamine and phloroglucinol. Physiol Mol Biol Plants 17(3):271-280

Siwach P, Gill AR, Kumari K (2011) Effect of season explants growth regulators and sugar level on induction and long term maintenance of callus cultures of Ficus religiosa L. Afr J Biotechnol 10(24):4879-4886

Swami KD, Bisht NPS (1996) Constituents of Ficus religiosa and Ficus infectoria and their biological activity. In Chem Soc 73:631

Swami KD, Malik GS, Bisht NPS (1989) Chemical investigation of stem bark of Ficus religiosa and Prosopis spicigera. J Ind Chem Soc 66:288-289

Tamara S, Al-Qudah, Rida A, Shibli, Feras Q, Alali (2011) In vitro propagation and secondary metabolites production in wild germander (Teucrium polium L). In Vitro Cell Dev Boil Plant 47:496-505

Vinutha B, Prashanth D, Salma K, Sreeja SL, Pratiti D, Padmaja R, Radhika S, Amit A, Venkateshwarlu K, Deepak M (2007) Screening of selected Indian medicinal plants for acetylcholinesterase inhibitory activity. J Ethnopharmacol 109(2):359-363 